\title{
Medical Healers in Ottoman Egypt, 1517-1805
}

\author{
SHERRY SAYED GADELRAB*
}

\begin{abstract}
Although the history of modern medical reforms in nineteenth-century Egypt has received considerable attention from historians and scholars, the history of medicine when the country was under Ottoman rule from the sixteenth to the eighteenth century, is still largely unexplored. ${ }^{1}$ In the opinion of many scholars this was a time when the medical sciences in Egypt declined, qualified learned physicians were rare and people relied mainly on ignorant barbers and charlatans, and the period was deemed unworthy of study. ${ }^{2}$ This lack of interest mainly stems from the opinion of the physicians who accompanied the French expedition of 1798-1801 and other European physicians assigned to reform medicine in early nineteenth-century Egypt. Foremost among these was the French surgeon Antoine-Barthélémy Clot-Bey, entrusted by Muhammad Ali Pasha, ruler of Egypt from 1805 to 1848, to reform the country's medical education and practice. Many of Clot-Bey's writings provided readers with a gloomy picture of the status of Egyptian health care. He maintained that Egyptians preferred quackery to rational medicine; there were no qualified practitioners, only barbers and midwives; therapeutics were primitive and limited; and, finally, medical techniques were barbarous and disastrous. ${ }^{3}$

Although such views had a long lasting influence on the study of the history of medicine in Ottoman Egypt, revisionist scholarship has warned against blindly accepting them. The comments of French writers on eighteenth-century Egyptian medicine, as J Worth Estes and LaVerne Kuhnke argue, reflected the perspective of Enlightenment scholars and physicians for whom European culture was superior to all others, and who regarded themselves as "torch bearers" of European civilization, art and science. ${ }^{4}$ Estes and Kuhnke's study shows that 78 per cent of the medical drugs used in Ottoman Egypt were also used in eighteenthcentury France for the same clinical purposes, because both western and Egyptian physicians
\end{abstract}

\section{(C) Sherry Sayed Gadelrab 2010}

* Sherry Sayed Gadelrab, Institute of Arab and Islamic Studies, University of Exeter, Stocker Road, Exeter, Devon, EX4 4ND, UK; e-mail: sherryge79@yahoo.com

\footnotetext{
${ }^{1}$ In 1805, Muhammad Ali Pasha rose to power in Egypt and introduced important changes to the administration, signifying the beginning of a new era. The nineteenth century witnessed wide-scale medical reforms including the institutionalization of medical education, regulation of medical practice and entry into the medical profession, the introduction of quarantine and compulsory vaccinations. The motives and consequences of these medical reforms are the subject of many studies including, Amira el Azhary Sonbol, The creation of a medical profession in Egypt,
}

1800-1922, Syracuse, NY, Syracuse University Press, 1991; Khaled Fahmy, All the Pasha's men: Mehmed Ali, his army and the making of modern Egypt, Cambridge University Press, 1997.

${ }^{2}$ Samir Yahya al-Jammal, Tarikh al-tibb wa al-saydalah al-mīsriyah, 5 vols, Cairo, al-Hay'ah al-Mișrīyah al-'Āmmah lil-Kitāb, 1999, vol. 4, p. 267; Jirjī Zaydān, Misr al- 'Uthmāniyah, Cairo, Dar al-Hilal, 1993, pp. 178-9; Jalāl Yahyà, Misr al-hadithah, Alexandria, 1969, pp. 188-91.

${ }^{3}$ Antoine-Barthélémy Clot-Bey, 'Esquisse des maladies les plus graves en Egypte', in idem, Introduction de la vaccination en Egypte en 1827, Paris, Victor Masson, 1860, pp. 1-4.

${ }^{4}$ J Worth Estes and LaVerne Kuhnke, 'French observations of disease and drug use in late eighteenth-century Cairo', J. Hist. Med. Allied Sci., 1984, 39: 121-52, p. 140. 


\section{Sherry Sayed Gadelrab}

still functioned within the system of humoralism. ${ }^{5}$ Other scholars have also successfully challenged some of the accepted statements about medical care in Ottoman Egypt. Michael Dols' study of medicine in sixteenth-century Egypt asserts that physicians were aware of the medical remedies used in Renaissance Europe, especially for the treatment of diseases that originated in the West such as syphilis. ${ }^{6}$

Despite the importance of these studies, certain areas of the history of medicine in Ottoman Egypt particularly that of medical practitioners, still requires more in-depth research. As has been pointed out, there is a tendency amongst historians of medicine in Muslim societies to focus only on the careers and writings of prominent physicians and the great institutions in which they practised medicine, with the aim of highlighting the important position that medicine and science occupied in Islamic society. ${ }^{7}$ With the exception of a few revisionist studies, historians have rarely questioned whether these well-known theoretical writings influenced hands-on medical practice, and have ignored the majority of medical practitioners who maintained everyday contact with their patients. ${ }^{8}$

Unfortunately, some scholars have assumed that the organization of medical practitioners remained unchanged from the medieval period until the nineteenth century. In her study of the history of the Arab medical profession, Anne-Marie Moulin argues that, contrary to what happened in post fifteenth-century Europe where medical education and practice were regulated by medical faculties, there were no effective means of regulating medical practice in pre-modern Arab states because of the absence of equivalent bodies. ${ }^{9}$ Similarly, Sylvie Chiffoleau's study of the nineteenth-century medical profession in Egypt suggests that the organization of pre-modern medical and paramedical craftsmen was rudimentary. Only barbers were organized in guilds, while the rest of medical practitioners, including physicians, were authorized to practise only after receiving an ijazāh, a certificate confirming that a student had mastered certain medical texts, and this was not an adequate means of ascertaining their ability to practise medicine. ${ }^{10}$ Yet, the evidence provided by records from law courts, manuscripts and other primary sources demonstrates that physicians, surgeons, oculists, bonesetters, barber-surgeons, apothecaries and midwives were all organized in guilds in Ottoman Egypt. This study aims to examine the extent to which the medical guilds played a role in the professional regulation of the medical practice of their members, supervised apprenticeship, and promoted work values among their members regardless of religious belief.

${ }^{5}$ Ibid., p. 139.

${ }^{6}$ Michael Dols, 'Medicine in sixteenth-century Egypt', in Ekmeleddin Ihsanoğlu (ed.), Transfer of modern science and technology to the Muslim world: proceedings of the international symposium on "Modern Sciences and the Muslim World", Istanbul, Research Centre for Islamic History, Art and Culture, 1992, pp. 213-19.

${ }^{7}$ Emilie Savage-Smith, 'Gleanings from an Arabist workshop: current trends in the study of medieval Islamic science and medicine', Isis, 1988, 79: 246-66, pp. 247-8; Miri Shefer, 'A tale of two discourses: the historiography of Ottoman-Muslim medicine', Soc. Hist. Med., 2008, 21: 1-12, pp. 3-6.

${ }^{8}$ For examples of these revisionist studies, see Michael Dols, Majnūn: the madman in medieval
Islamic society, Oxford, Clarendon Press, 1992; idem, The Black Death in the Middle East, Princeton University Press, 1977;

Peter E Pormann and Emilie Savage-Smith, Medieval Islamic medicine, American University in Cairo Press, 2007.

${ }^{9}$ Anne-Marie Moulin, 'La profession médicale dans les pays arabes: vues historiques à long et à court terme', in Brigitte Curmi and Sylvie Chiffoleau (eds), Médecins et protection sociale dans le monde arabe, Beirut, CERMOC, 1993, pp. 223-45.

${ }^{10}$ Sylvie Chiffoleau, Médecines et médecins en Egypte: construction d'une identité professionelle et project médical, Lyons, Maison de l'Orient Méditeranéen, 1997, pp. 113-14. 
But, as will be shown, despite their best efforts the medical guilds did not have total control over medical practice. The plurality of the medical system made this impossible. The lack of consensus on where medical authority lay is reflected in the large number of medical healers who acquired their knowledge and skills through a variety of ways, and who employed interchangeably different sources of medical knowledge: Galenic, prophetic, astrological, magical and folk medicine, for the treatment of their patients.

\section{Medicine: Science or Craft?}

The medieval and pre-modern controversy over whether medicine should be defined as a science or a craft, is a striking feature of the pluralist medical system in Ottoman Egypt. Intellectuals and scholars conceived of medicine sometimes as a science and sometimes as a craft. Theoretical medical knowledge, regarded as part of 'ilm (knowledge), enjoyed a prestigious position among the rational sciences, while practical medicine was considered a manual skill. In his al-Muqaddimah, the Muslim scholar Ibn Khaldūn defined medicine as a subdivision of physics, and a science concerned with studying the different types of illnesses and their causes, as well as the composition, uses and effectiveness of each medicine. The science of medicine could be studied by anyone, regardless of their religion, as long as they were qualified to learn. ${ }^{11}$ In another passage of his book, however, Ibn Khaldūn referred to medicine as a craft, but a noble one, because it deals with the human body, and he grouped it with other necessary crafts such as agriculture, carpentry and tailoring. ${ }^{12}$ Like these, medicine was concerned with action and thus best taught through practice and the personal observation of a master. ${ }^{13}$ In the sixteenth and seventeenth centuries, the Turkish scholars Ahmad ibn Mustafá Ṭāshkubrī'zādah and Hājjjī Khalīfah differentiated between medicine as a science whose objective is the study of disease and the restoration of health, and other branches of medicine that require a manual skill such as surgery, which they considered more of a craft than a science. ${ }^{14}$

Doris Behrens-Abuseif's study of the physician as portrayed in Mamluk and Ottoman chronicles and biographical dictionaries confirms that scholars distinguished between theoretical and professional medicine. Mamluk and Ottoman chronicles and biographical dictionaries, written by 'ulamā (scholars in Islamic law) and intellectuals, contained many references to religious scholars who acquired theoretical medical knowledge as an aspect of erudition but never actually practised medicine, but they rarely mentioned professional medical practitioners, who were considered mere craftsmen. ${ }^{15}$ In his protocol hierarchy of Fatimid and Mamluk government, the medieval Egyptian writer and mathematician al-Qalqashandī (d. 1418) included physicians, oculists and other medical practitioners among the craftsmen (ahl al-hiraf wa al-sin' 'àt). ${ }^{16}$

\footnotetext{
11 'Abd al-Raḥmān ibn Muhammad Ibn Khaldūn, al-Muqaddimah, 3 vols, trans. Franz Rosenthal, New York, Pantheon books, 1958, vol. 3, pp. 111-12.

${ }^{12}$ Ibid., vol. 2, pp. 355-6, and vol. 3, p. 148.

${ }^{13}$ Ibid., vol. 2, p. 346.

${ }^{14}$ Ahmad ibn Mustafá Ṭāshkubrī’ zādah, Kitāb miftāh al-sa 'ādah wa misbàh al-siyādah fi mawd̄̄ 'àt al-'ulūm, 2 vols, Cairo, 1911, vol. 1, pp. 285-6; Hājjī Khalīfah, Kitāb kashf al-zunūn'an Asāmī
}

al-kutub wa-al-funūn, 2 vols, Istanbul, 1892, vol. 1, p. 386.

${ }^{15}$ Doris Behrens-Abouseif, 'The image of the physician in Arab biographies of the post-classical age', Der Islam, 1989, 66: 331-43, p. 336.

${ }^{16}$ Doris Behrens-Abouseif, Fath Allāh and Abu Zakariyya: physicians under the Mamluks, Cairo, Institut Français d'Archéologie Orientale, 1987, p. 4. 


\section{Sherry Sayed Gadelrab}

This dual definition of medicine in medieval and Ottoman Egypt explains the different means through which medical practitioners understood medicine and acquired medical knowledge and skills. For some scholars as well as some physicians, medicine was an academic activity, learnt through reading and memorizing theoretical medical literature. For others, the majority of healers, medicine was a skill mastered through apprenticeship and practical training.

\section{'Ulamā and Medical Knowledge}

In medieval and early modern Egypt, many 'ulamā studied medicine, as well as other rational sciences, to fit the image of the scholar with encyclopaedic knowledge, the erudite man of the time. For example, the prolific scholar Sheikh 'Abd al-Raū'f al-Munāwī (d. 1621) was known for his knowledge of medicine and anatomy in addition to astronomy, logic and hadith (science of prophetic traditions). He was described by his biographers as the man who "masters many sciences that none of his contemporaries could know". ${ }^{17}$ Al-Munāwī also wrote two medical works, yet there is no indication in his biography of his practising medicine. Likewise, the biography of Sheikh Ahmad al-Qalyūbī (d. 1658)-author of Tadhkirat al-Qalyūbì (Prescriptions of al-Qalyūbī), a popular medical manual in Ottoman and nineteenth-century Egypt—does not indicate that he actually practised medicine. ${ }^{18}$ The fact that religious scholars studied medicine and even wrote medical treatises without any clinical experience, is explicable within the intellectual context of the period in which the science of medicine was considered an academic endeavour. The religious scholar would usually gather and recopy medical information and remedies from earlier medical literature in his own books, without necessarily knowing whether such treatments were effective.

A religious scholar usually acquired knowledge of theoretical medicine in the same way that he studied the theoretical sciences such as Islamic jurisprudence, prophetic traditions and Arab literature. He would read and memorize medical books under the tutorship of another 'álim (scholar) or even a physician, after which he received an ijazāh stating that he had read and studied a certain medical book. The eighteenth-century religious scholar Sheikh Ahmad al-Damanhūrī (d. 1768) studied medicine under Badr al-din al-Qarāfī al-Hakim, a physician, after which he received an ijazāh stating that he had read Ibn al-Nafis' al-Mūjiz, al-Majūsī's Kämil al-șinā 'ah al-tibbìyah, and Ibn Sīnā's al-Urjūzah fi al-tibb. ${ }^{19}$

\section{Healers as Men of Learning}

The two strands of medicine also influenced the way medical healers, particularly physicians, acquired medical knowledge and skills. In Ottoman Egypt, the education of some physicians, whom we will refer to as academic physicians, was mainly theoretical, with little emphasis on clinical training. The biographies of academic physicians reveal that reading and learning medical textbooks was the most common feature of their medical education. Biographers usually use terms such as qara'a al-tibb (read medicine or medical books) or

\footnotetext{
${ }^{17}$ Muhammad Amīn al-Muhibbī, Khulāasat al-athar fi a 'yan al-qarn al-hādì 'ashar, 4 vols, Beirut, Dar Sadr, [1966], vol. 2, p. 412.

${ }^{18}$ Ibid., vol. 1, p. 175.
}

\footnotetext{
${ }^{19}$ Fuad al-Hifnawi, 'Al-Ṭibb fi al-azhar qadiman wa hadithan', in 'Abd al-Rạ̣mān al-'Awadi (ed.), Al-Tibb al-Islami: al-abhath a'mal al-mu'tamar al-thani 'an al-tibb al-islami, Kuwait, mu'assasat al-kuwayt lil taqaddum al-'ilmī, 1982, p. 814.
} 
dhakr kutub al-tibb (studied the books of medicine) to describe the type of medical education academic physicians received. A properly educated academic physician was expected to be well-versed in classical medical literature, such as Hippocrates' Fusül abuqrät, Ibn Sīnā's al-Qānūn and Ibn al-Nafis' al-Müjiz. ${ }^{20}$

The academic reputation of a teacher seems to have influenced the career of a future academic physician, and thus biographers were keen to mention their names. The majority of notable academic physicians learnt medicine from their fathers or other members of their family, who were in turn, famous academic physicians such as Sheikh Sari Eldin al-Șāigh, who read medical books with his father (qara' a al-tibb 'ala abihi). ${ }^{21}$ Others were the disciples of physicians to whom they were not related. The Egyptian seventeenth-century physician Sheikh Madian Ibn 'Abd al-Rahmān al-Qawșūni, for example, studied medicine under Dāwūd Ibn 'Umar al-Anțākī (d. 1599). ${ }^{22}$

In addition to studying medicine, academic physicians were distinguishable by their broad education in a wide range of academic fields. The sophisticated and diversified knowledge of academic physicians earned them the title of hakim (wise man), and distinguished them as men of learning. The sixteenth-century physician Dāwūd al-Anțākì was well read in many rational sciences including philosophy and mathematical sciences. ${ }^{23}$ His biographer al-Muhibbī described him as the "Ibn Sinnā of his time" and "notable for his knowledge of the ancient sciences" (al-mutafarrid bi "ulüm al-awā'il), who always provided long and detailed answers to any questions put to him about the natural and physical sciences. Similarly, Madian Ibn 'Abd al-Raḥmān al-Qawsūnī was not only learned in medicine and other rational sciences, but he also studied history and literature. ${ }^{24}$

Following a tradition that has its roots in ancient Greek and medieval Greco-Islamic medicine, many academic physicians believed that a knowledge of certain sciences besides medicine was essential in a good physician. A physician's expertise in philosophy, astronomy, botany and other sciences was used as the main criterion to differentiate between a physician $\left(t_{a b i} \bar{\imath}\right)$ and a general practitioner (mutatabibb) in medieval Muslim societies. ${ }^{25}$ Early modern physicians continued to defend the importance of mastering medical theory and a multi-disciplinary education for a good physician. The seventeenth-century physician Sari Eldin al-Saaigh, for example, cautioned that no physician had the right to touch the bodies of his patients or to treat people unless he had read the basic medical textbooks, such as Ibn Sīnā's al-Qānūn. He criticized the physicians (atibbā') of his time who had no knowledge of sciences such as logic or astronomy, and accused them of being negligent and remiss. ${ }^{26}$ Similarly, Dāwūd al-Anțākī regarded most of those who practised medicine during his time as "pretenders" to the art of medicine, because they studied medicine only through short medical commentaries, which he believed to be inadequate. ${ }^{27}$

\footnotetext{
${ }^{20}$ Ahmad al-Saigh al-Hanafi, 'Rīsālah fi mabāhath al-țibb', manuscript held in Dār al-kutub al-Misrīyah, Cairo, tibb 543, fols 10a.

${ }^{21}$ Al-Muhibbī, op. cit., note 17 above, vol. 1, pp. 203-4.

${ }^{22}$ Ibid., vol. 4, pp. 333-4.

${ }^{23}$ Ibid., vol. 2, pp. 140-9.

${ }^{24}$ Ibid., vol. 4, pp. 333-4.

${ }^{25}$ Gary Leiser, 'Medical education in Islamic lands from the seventh to the fourteenth century',
}

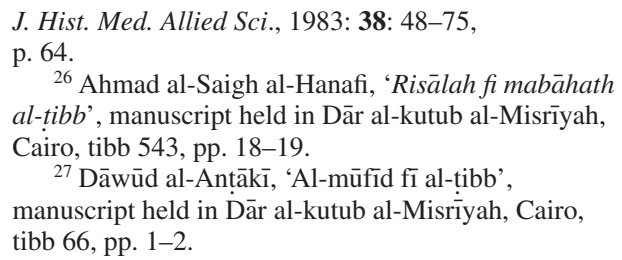

${ }^{27}$ Dāwūd al-Antākī, 'Al-mūfīd fī al-tibb', manuscript held in Dār al-kutub al-Misrìyah, Cairo, tibb 66, pp. 1-2. 


\section{Sherry Sayed Gadelrab}

Learned physicians' claims to superiority over other physicians (mutatabibün), because of their academic achievements should be seen within the framework of Greco-Islamic medical traditions. Learned medicine in Europe and the Ottoman empire up until the eighteenth century was based upon the humoral system which defined disease as an imbalance of bodily humours caused by a disturbance of the six non-naturals: diet, environment, rest and wakefulness, exercise, evacuation of bodily residues. Thus, disease was the result of a disequilibrium in an individual's diet, habits or lifestyle. A physician's task, according to this medical system, was not to fight the disease but to evaluate the sick person's way of life and restore harmony to his or her body. The long humanist training of learned physicians, despite limited clinical preparation, was not unrelated to their role as physicians because their education aimed "at transforming the student into a physician of good character who could exercise good judgment and advice: a man of learning". ${ }^{28}$ Medieval and early modern Islamic deontological and medical literature stressed that the aim of a physician's education was mainly to discipline his or her character and soul (tadbïr al-shakhs wa tahdhib al-nafs), stressing the moral character of a physician rather than his professional qualifications. ${ }^{29}$ Rationality, patience, the ability to control one's desires were among the most important qualifications that, according to Dāwūd al-Antākī, every good physician should have. ${ }^{30}$

Apart from these ancient and medieval medical values, the wide ranging education of academic physicians could also be seen as a means for them to raise their social and economic status and thus distinguish themselves from the rest of medical practitioners, regarded simply as craftsmen. When the sixteenth-century Venetian physician Prospero Alpini visited Egypt, he observed a large number of male and female physicians practising in Cairo and other parts of Egypt who lacked prestige and had low incomes. ${ }^{31}$ Alpini's comments should be interpreted within the context of his background as a learned physician in sixteenthcentury Europe, where physicians were the self-proclaimed elite of medical practitioners whose services only the rich could afford. Academic Egyptian physicians probably shared the same attitude towards their non-academic counterparts and other medical practitioners, believing their own elaborate and refined education defined them as men of learning who could mingle with the intellectual elite. The biographies of academic physicians indicate that they had stronger links with judges, religious scholars and men of learning than they did with other practitioners. In his account of the Syrian physician Ibn al-Ghazzal, alMuhibbī commented that his sophistication and wit allowed him to mingle with the elite and distinguished him from "other medical craftsmen" (arbāb al-șina'āh). ${ }^{32}$ In addition to boosting their social status, physicians' knowledge of different sciences influenced their economic status, allowing them to find other forms of employment besides medicine. As well as being Head of the Physicians' Guild, Sheikh Ahmad al-Șäigh was also the teacher of Hanafi law in al-Barqūqiyah school. ${ }^{33}$ Sheikh Qāssim Ibn Muhammad al-Tūnisī was both a physician and a teacher of prophetic traditions in al-Azhar.

\footnotetext{
${ }^{28}$ Harold Cook, 'Good advice and little medicine: the professional authority of early modern physicians', J. Br. Stud., 1994, 33: 1-31, p. 4.

${ }^{29}$ Ishaq ibn Ali al-Rahawi, Adab al-tabīb, ed. Murayzin Said Murayzin, al-Riyad, 1992, pp. 55-8; Dāwūd al-Anțākī, Tadhkirat uऍ al-albāb wa al-jami' lil-'ajab wa al-'ujāb, Cairo, 1903, pp. 5-7.
}

\footnotetext{
${ }^{30}$ Dāwūd al-Anțākī, op. cit., note 29 above, p. 4.

${ }^{31}$ Prosper Alpin, La médecine des égyptiens (1581-1584), trans. R de Fenoyl, Cairo, Institut Français d'Archéologie Orientale, 1980, p. 14.

${ }^{32}$ Al-Muhibbīi, op. cit., note 17 above, vol. 3, p. 299.

${ }^{33}$ Ibid., vol. 1, p. 203.
} 
Although the broad education of the academic physicians could grant them a better social standing than the rest of medical practitioners, their reputation in treating the sick was judged on other criteria. Biographers differentiated between the academic physicians' knowledge of the science of medicine and their skill in the practice of medicine, pointing out that some were not successful because of their lack of clinical practice. The fifteenthcentury Egyptian historian al-Sakhāwī was critical of some of his contemporary academic physicians' medical skills, despite his admiration of their medical erudition. For example, Sirāj al-Din al-Bahādrī led his colleagues in his great ability to memorize medical texts, but his treatments, according to al-Sakhāwī, were not successful because medicine was not his main profession, and thus he lacked experience and was only consulted by the elite in difficult cases ${ }^{34}$ Other historians blamed the bad luck of some academic physicians on their failure to cure their patients. The Syrian historian al-Ghazzī commented that although Muhammad Ibn Mikkī was more knowledgeable than any of his colleagues in the sciences of medicine astronomy and geometry, he "had little luck in treating his patients". ${ }^{35}$ Although al-Sakhāwī and al-Ghazzī, themselves men of learning, may have admired academic physicians, like most people, they clearly differentiated between academic reputation and the effective treatment of a disease.

\section{Healers as Craftsmen}

The majority of medical practitioners who were responsible for dispensing medical care to people on an everyday basis were simply craftsmen who relied on apprenticeship and practical experience to perfect the techniques of their craft. Alpini commented that most practising Egyptian physicians were barely familiar with medical theory and learnt medicine mainly through their empirical experience. They were concerned with the treatment of a disease rather than with discovering its essence, nature and causes. ${ }^{36}$ The fourteenth-century historian Ibn Hajar al- 'Asqalānī tells us of Sulaymān Ibn Dāwūd, a talented physician who learnt medicine through experience and knew nothing of hikmah (in other words, did not study theoretical medical science or other sciences), but, none the less, he became the Head of the Physicians ( $r a^{\prime} \bar{l} s$ al-atibbà' —an honorary title) because of his skill. ${ }^{37}$ The tasks of surgeons, barber-surgeons, oculists, bonesetters, apothecaries and midwives entailed manual skills, which they learnt mainly through apprenticeship and practical training. ${ }^{38}$

Given the available theoretical medical knowledge and its modes of transmission, we can interpret the wide gap between medical theory and practice. The majority of therapeutic and surgical medical literature in medieval Islam was written by Greek and Roman authorities, then translated, copied and organized by medieval physicians in Muslim societies. The latter were not passive copyists but also contributed their own discoveries to

\footnotetext{
${ }^{34}$ Muhammad Ibn 'Abd al-Raḥmān al-Sakhāwī, al-Daw' al-lāmi' li-ahl al-qarn al-tāsi, 12 vols, Beirut, Dar Maktabat al-Hayah, 1966, vol. 6, p. 139.

${ }^{35}$ Muhammad ibn Muhammad al-Ghazzī, al-Kawākib al-sā'irah bi a'yān al-mi'ah al-'āshirah, Beirut, Dar al-Afaq al-jadidah, 1979.

${ }^{36}$ Alpin, op. cit., note 31 above, p. 14.

37 Ibn Hajar al-'Asqalānī, al-Durār al-Kāminah fi a'yān al-mā'ah al-thāminah, ed. Muhammad Sayyid
}

Gad al-Haq, 4 vols, Cairo, Dar al-kutub al-hadithah, 1966-1967, vol. 2, p. 246.

${ }^{38}$ Sami K Hamarneh, Health sciences in early Islam, ed. Munawar A Anees, 2 vols, Blanco, Texas, Zahra publications, 1984, vol. 2, pp. 175-82; Tāshkubrī'zādah, op. cit., note 14 above, vol. 1, pp. 285-6; Hājjī Khalīfah, op. cit., note 14 above, vol. 1 , pp. 386,390 . 


\section{Sherry Sayed Gadelrab}

different medical fields including anatomy and pathology. Many of these medical recipes and surgical procedures, copied from earlier authorities, were never, or rarely, tested or used for treating patients. A comparison of the extensive therapeutic literature compiled by physicians in medieval Muslim societies with their casebooks demonstrates the discrepancy between theory and actual practice, which usually relied on bloodletting, purgatives and a limited number of medical remedies. ${ }^{39}$ Many of the complicated surgical procedures, described by famous medieval surgeons such as Abū al-Qāsim al-Zahrāwī (known in Europe as Albucasis) were rarely carried out in everyday medical practice. ${ }^{40}$ The situation was not much different in pre-modern Egypt. Although Dāwūd al-Anțākī listed many medical simples and compounds in his books, my analysis of the treatments he recommended for diseases such as plague, syphilis, ophthalmia, leprosy, smallpox, elephantiasis, dizziness, dysentery, headaches, and tumours shows that bleeding and cupping were what he most commonly prescribed. He also made use of a limited number of drugs: myrtle, jujube, barley water, plum, oxymel, tamarind, scammony, sandalwood and ceruse, each of which could be used for the treatment of at least three diseases. ${ }^{41}$

The difference between medical theory and practice does not mean that medical practice was declining. The empirical experience of medical craftsmen allowed them, sometimes, to improve the medical techniques or therapeutics prescribed in theoretical medical literature. Alpini was impressed by the surgical techniques of local Egyptian surgeons in bloodletting, cupping, cauterization and stone removal, many of which contradicted or were different from Galenic instructions. Yet they were, according to him, successful and more practical than those described in the medical literature of ancient authorities and still employed by European physicians of his time. Likewise, the Egyptian method of treating typhus by wrapping the patient in heavy cloths to provoke sweating, and then washing his or her head with cold water, was so admired by the physicians accompanying the French expedition that they took up the method themselves, when their own had failed. ${ }^{42}$

Although medical artisans acquired their skills mainly through empirical experience and apprenticeship, some were literate and familiarized themselves with medical texts relevant to their specializations. There is evidence that medical textbooks, surgical and pharmaceutical manuals continued to be copied intensively in the Ottoman period, which suggests a wide readership. The inheritance records of some medical craftsmen show that they had medical textbooks in their libraries. ${ }^{43} \mathrm{~A}$ few were keen to have proof of their knowledge, and to this end studied textbooks with persons experienced in their fields eventually receiving an ijazāh. Shams al-din Muhammad Ibn 'Azzām al-Jirwān̄̄, a barber-surgeon, received an ijazāh from the Head of the Physicians' Guild after mastering a medieval surgical manual on

\footnotetext{
${ }^{39}$ Pormann and Savage-Smith, op. cit., note 8 above, pp. 114-19; Cristina Alvarez-Millán, 'Practice versus theory: tenth-century case histories from the Islamic Middle East', in Emilie Savage-Smith and Peregrine Horden (eds), The year 1000: medical practice at the end of the first millennium, Oxford University Press for the Society for the Social History of Medicine, 2000, pp. 293-304, on p. 293.

${ }^{40}$ Pormann and Savage-Smith, op. cit., note 8 above, pp. 124-5.
}

\footnotetext{
${ }^{41}$ Dāwūd al-Antākī, op. cit., note 29 above, vol. 2, pp. 34, 60, 63, 65, 79-80, 89, 121.

${ }^{42}$ La Décade Égyptienne, Journal Littéraire et d'Économie Politique, 1798-1801, 6: 222-7, as cited in Sonbol, op. cit., note 1 above,

${ }^{43}$ Nelly Hanna, In praise of books: a cultural history of Cairo's middle class, sixteenth to the eighteenth century, Syracuse, NY, Syracuse University Press, 2003, p. 94.
} p. 9. 
bloodletting. ${ }^{44}$ Muhammad Ibn Qayyim al-Hallāq, another barber-surgeon, also received an ijazāh (dated 1602) for writing a medical treatise on cupping and bloodletting. ${ }^{45}$ Although some modern scholars such as Ahmad 'İsā considered the ijazāh equivalent to a licence to practise and thus a main tool for regulating the practice of medicine, its importance should not be overestimated. ${ }^{46}$ As evidence of students' theoretical knowledge, the ijazāh carried little weight when medical craftsmen were valued for their practical skills. Since the majority of medical craftsmen were trained through apprenticeship, the ijazāh should be regarded as the exception rather than the rule. However, some medical practitioners possibly sought it to elevate their social status and mingle with the better-educated members of their guilds or as a further credential to gain a reputation of being learned as well as skilled amongst their clients in a competitive medical marketplace.

The patients, regardless of their economic and social backgrounds, were mainly concerned with the skills of these practitioners and the success of their treatments rather than with their education. Most medical practitioners were no different from other craftsmen and tradesmen in the marketplace. Although some were employed in hospitals such as alBīmāristān al-Manșūrī, the majority offered their services in hawānìt (shops). However, the talent and experience of some in treating disease paved the route for them to have rich and powerful clients. Miri Shefer's study of court physicians concludes that most were "practitioners for whom medicine was not an intellectual activity but more of a craft". ${ }^{47}$ 'Abd al-Raḥmān ibn Musá al-Munūfī, a fifteenth-century oculist who practised his art in front of the mosque of Qusūn, was "so talented in kuhl [treatment of eye diseases] that he attracted crowds of people and became so famous that he had many apprentices". ${ }^{48}$ In late Mamluk Egypt, Sheikh Jamāl el-din Ibn 'Abd al-Hak occupied the positions of court surgeon and Head of the Surgeons (an honorary title bestowed by the state) because he was distinguished in his craft (tamayzihì fi sina'ātihì $).{ }^{49}$

In this context, we can explain the popularity of some medical practitioners, such as barber-surgeons, who were later blamed for the decline of medical practice in nineteenthcentury Egypt. A barber-surgeon (muzayn) who had mastered the art of his craft, might well have rich and educated clients, even though he himself was illiterate. In his account of 'Abd Allah ibn 'Abd al-Hak, a surgeon, al-Sakhāwī tells us that the father of 'Abd Allah, Jamal al-din, Head of the Physicians, decided that his son would become a surgeon when he saw the amazingly large sum of money that a barber-surgeon received after circumcising the son of the Mamluk Sultan Faraj ibn Barqūq. ${ }^{50}$ In 1133/1720, when the Mamluk Emir Yusuf al-Jazzār became ill, he relied on the medical services of the muzayn, who cauterized the Pasha and successfully treated him. ${ }^{51}$

${ }^{44}$ Ahmad 'Īsā, Tārìkh al-Bīmāristānāt fi al-Islām, ed. Ibrahim al-Hawarim, Dār al-Rā'id al- 'Arabī, 1981, pp. 44-5.

${ }^{45}$ Ibid., pp. $46-7$.

${ }^{46}$ Ibid., pp. 41-3.

${ }^{47}$ Miri Shefer, 'Physicians in Mamluk and Ottoman courts', in David Wasserstein and Ami Ayalon (eds), Mamluks and Ottomans: studies in honour of Michael Winter, London, Routledge, 2006, pp. 114-22, 118.
${ }^{48}$ Al-Sakhāwī, op. cit., note 34 above, vol. 4, pp. 152-3.

${ }^{49}$ Ibid., vol. 4, pp. 22-3.

${ }^{50}$ Ibid.

${ }^{51}$ Ahmad Shalabī Ibn 'Abd al-Ghan̄i, Awdah al-ishārāt fiman tawallá Misr al-Qāhirah min al-wuzarā' wa al-bāshāt, Cairo, Dar al-Ansar, 1977, pp. 346-7. 


\section{The Role of the Medical Guilds}

Various primary sources confirm that the majority of medical practitioners, including physicians, were organized in professional guilds between the sixteenth and the eighteenth century. Using an Egyptian seventeenth-century manuscript as a basis, Gabriel Baer has referred to the guilds of physicians, surgeons, barbers, midwives, apothecaries and makers of medical pastes (ma'jünatiyāh). ${ }^{52}$ André Raymond's study of merchants and craftspeople in eighteenth-century Egypt also mentioned the guilds of physicians, surgeons, apothecaries and ma'jünatiya $h^{53}$ The records of the law courts confirm that each group of medical practitioners had their own professional corporation, responsible for managing their affairs and headed by a member of the guild. ${ }^{54}$

There are conflicting opinions among historians as to when the guilds began in the Arab world in general. Although some scholars such as Bernard Lewis have argued that professional organizations began in the third/ninth century, others, such as Claude Cahen and Gabriel Baer, maintained that guilds appeared in the Arab Muslim world only during Ottoman rule in the sixteenth century under Turkish Anatolian influence. ${ }^{55}$ Others such as Raymond suggest that there could have been professional communities before the sixteenth century under the control of the muhtasib, an office of a religious and judicial nature usually occupied by a judge or a religious scholar assigned to supervise merchants, tradesmen and craftspeople. The sixteenth century, however, was a turning point, when the muhtasib's role became limited to supervising food-related trades, while the majority of craftsmen and merchants were regulated through their own guilds. ${ }^{56}$

This argument is particularly applicable to medical guilds in Egypt before the sixteenth century. Although there are references to the Head of the Physicians in Mamluk Egypt (1250-1517), there is no evidence that he took over the supervisory duties of the muhtasib. In fact, manuals of market inspection ( $h \bar{l} s b a h$ ) produced during that period include information for guiding the muhtasib in his supervision of the various medical crafts, which means that he was still responsible for supervising physicians and other medical practitioners. ${ }^{57}$ But his supervisory duties were restricted to food-related trades only, while guilds of other crafts assumed a significant regulatory and supervisory role in the sixteenth

\footnotetext{
${ }^{52}$ Gabriel Baer, Egyptian guilds in modern times, Jerusalem, Israel Oriental Studies, 1964, p. 37.

${ }^{53}$ André Raymond, Artisans et commerçants au Caire au XVIII siècle, 2 vols, Cairo, Institut Français d'Archéologie Orientale, 1974, vol. 2, pp. 551, 568; idem, 'Une liste de corporations de métiers au Caire en 1801', Arabica, 1957, 2: 157-63.

${ }^{54}$ I have employed a number of legal documents concerning medical guilds in the seventeenth century. Some of these are published and referred to by Ghazaleh, see note 65 below; for guilds in Ottoman Egypt, see Shuman, note 75 below. Additionally I have based my analysis on a random sample of other unpublished legal documents from the seventeenth century held in the National library of Archives, Cairo.

${ }^{55}$ Bernard Lewis, 'The Islamic guilds', Econ. Hist. Rev., 1937, 8: 20-37; Claude Cahen, 'Y a-t-il eu des corporations professionelles dans le monde musulman classique?', in Albert H Hourani and
}

Samuel M Stern (eds), The Islamic city, Oxford, Cassirer, 1970, pp. 51-63; Gabriel Baer, 'Guilds in Middle Eastern history', in

M A Cook (ed.), Studies in the economic history of the Middle East, Oxford University Press, 1970 pp. 11-30.

${ }^{56}$ André Raymond, 'Sinf', Encyclopedia of Islamic Online, www.brillonline.nl (accessed 12 Feb. 2008).

${ }^{57}$ Hisbah manuals continued to be composed throughout the Mamluk era, see, for example, Muhammad ibn Muhammad ibn al-Ukhūwah, Kitāa ma 'àlim al-qurbah fi ahkām al-ḥisbah, Cairo, al-Hay'ah al-Misrīyah al-'Āmmah lil-Kitāb, 1976; Sihām Mustafá Àbū Zayd, al-Hisbah fi Misr al-islāmiyah min al-fath al- 'Arabì ilá nihāyat al- 'asr al-mamlūkè, Cairo, al-Hay'ah al-Mișrīyah al- 'Āmmah lil-Kitāb, 1986. 
century. ${ }^{58}$ By forming themselves into guilds, medical craftsmen were only copying developments in most crafts and trades. Thus, a deeper understanding of medical guilds and their role in Ottoman Egyptian society should be based on an understanding of guilds in general, their internal organization, and the dynamics through which they carried out their duties.

The guilds occupied an important position in Ottoman Egypt. Galal El-Nahal refers to them as units of economic organization in Ottoman Egyptian society ${ }^{59}$ which served the interests of both the state and the craftsmen. The guilds were responsible for safeguarding the interests of their members, limiting access to their crafts and trades, as well as regulating the quality of their services and products. As for the state, the guilds provided a labour force and expertise when needed. ${ }^{60}$ The internal organization of all guilds was designed to fulfil these duties. Medical guilds were structured hierarchically. Each one was headed by a Sheikh, who was usually chosen or elected by guild members. The judicial court usually confirmed their choice by issuing a hujjāh (document of investiture) to that effect. In large cities each major district had its own medical guild. The heads of the medical guilds in these districts came under the authority of the head of their guild in Cairo. A legal record, for example, refers to the heads of the guilds of surgeons in the districts of Misr al-qadimah, and al-Khanqah. However, they were all under the supervision of the head of the guild of surgeons in Cairo. ${ }^{61}$ A seventeenth-century deed of investiture of the Head of the Surgeons' Guild reveals much about his duties and the qualifications required. The Sheikh of the guild was the spokesman for the members of his craft, indicating that he acted as an intermediary between authorities of the state and guild members. The deed specifies that the Sheikh was responsible for supervising surgeons and barber-surgeons as well as checking their tools, according to ancient customs and regulations. The Sheikh was chosen on the basis of his merit, honesty, expertise and knowledge of the techniques of the craft. ${ }^{62}$ The deed shows that the consequences of organizing medical craftsmen into guilds were important. First, the replacement of the muhtasib by the medical guilds meant that medical craftsmen became subject to professional rules and regulations set and supervised by expert practitioners rather than an outsider. As a non-professional, the ability of the muhtasib to supervise medical craftsmen is debatable. Max Meyerhof has questioned the ability of the muhtasib to regulate medical practice effectively because his regulatory duties included overseeing certain medical techniques which required more profound knowledge of medicine and medical skills than those possessed by a layman. ${ }^{63}$ As the deed demonstrates, the head of a guild became responsible for monitoring medical practice and the techniques of his fellow craftsmen, which explains the emphasis on his skill and expertise in the craft.

The deed of investiture uses terms such as "old rules" and "correct practice" which indicate that medical guilds established and followed certain professional rules and regulations common to their needs. Unfortunately, no written version of these rules has survived, yet we get a glimpse of some which are mentioned in legal accounts of cases when medical

\footnotetext{
${ }^{58}$ Raymond, op. cit., note 53 above, vol. 2, pp. 588-600.

${ }^{59}$ Galal $\mathrm{H}$ El-Nahal, The judicial administration of Ottoman Egypt in the seventeenth century, Minneapolis, Bibliotheca Islamica, 1979, p. 57.

${ }^{60}$ Pascale Ghazaleh, 'The guilds: between tradition and modernity', in Nelly Hanna (ed.), The state and its servants: administration in Egypt from
}

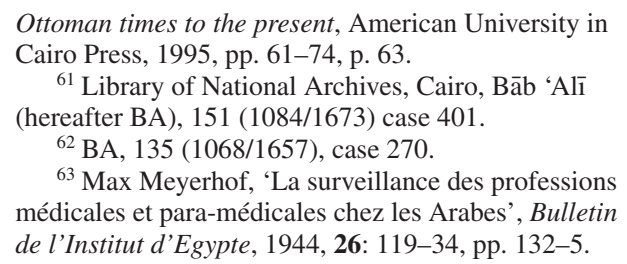

${ }^{63}$ Max Meyerhof, 'La surveillance des professions médicales et para-médicales chez les Arabes', Bulletin de l'Institut d'Egypte, 1944, 26: 119-34, pp. 132-5. 


\section{Sherry Sayed Gadelrab}

practitioners breached these laws. On the basis of this limited information we can conclude that these rules concern medical standards agreed upon by the members of each medical guild, as well as guidelines ensuring the ethical behaviour of medical practitioners towards their patients. Sheikh Nūr al-Ziftāwī, Head of the Surgeons' Guild in Cairo, was brought before a court of law because of the repeated complaints of bad treatment, lack of attention and pity, made by his patients. The Qadi (judge) consulted the Head of the Physicians, Sheikh Shirbīn̄i and Sheikh Ahmad al-Nashmātī, a master oculist, who upheld the complaints, and recommended al- Ziftāwī be replaced by another surgeon, Sheikh al-Qadirī, known for his honesty and profound knowledge of the art of surgery. ${ }^{64}$

Although the head of a medical guild was responsible for supervising guild members, the mechanisms by which he was supposed to carry out his duties were more complex. As Ghazaleh shows, primary sources assert that the Sheikh of a guild did not have the ultimate authority to prosecute those who breached the laws. ${ }^{65}$ To punish a medical practitioner, or prevent him or her from practising medicine, the Sheikh had to resort to the legal process. The Sheikh could ask the Qadi to ban a craftsman from practising because he or she did not abide by the standards of the craft. Sometimes cases of malpractice were brought independently by patients to the attention of the judge, who in turn, would consult the head of the appropriate medical guild and other master craftsmen in the guild. If a practitioner was found guilty of malpractice, the Qadi alone could withdraw the right to practise medicine. ${ }^{66}$ This legal procedure provided the state with some control over the guilds while at the same time reassuring guild members that the rules and regulations were respected.

The archives of the law courts shed light on the role played by the guilds in supervising apprenticeship and guaranteeing the qualifications of potential craftsmen. The most common path for a potential medical practitioner to learn the techniques of his or her craft was a period of apprenticeship under a master craftsman. A mu'allim-an Arabic term for a teacher-would be responsible for teaching the apprentice and guaranteeing his qualifications. The transition of an apprentice from one level to another was usually documented in court records. A mu'allim, along with some members of the guild as witnesses, would usually testify before the court that the apprentice had mastered the techniques of the craft and could thus be permitted to exercise the profession, join the mu'allims, enjoy the same rights and fulfil the obligations required of all members of the guild. ${ }^{67}$

The guild's concern to protect the interests of its members is reflected in the institution of jedi $k$ (a licence granted by the guild without which a craftsman could not open a shop). Once his professional training was completed, a craftsman would undergo an initiation ceremony (shadd) at which he was presented with a jedi $k$ from the guild signifying that he had become a qualified craftsman. The jedi $k$ provided security for medical craftsmen, maintained the guild's control over who could exercise the craft (at least in shops) as well as guaranteeing the quality of service provided. ${ }^{68}$

The guild also made use of the courts to prevent unqualified apprentices from exercising medicine. In a seventeenth-century case, Mustafà Ibn 'Abd Allah, the Head of the Surgeons' Guild, complained that Muhammad al-Hāwē, who had served his apprenticeship with a

${ }^{64} \mathrm{BA}, 128$ (1060/1649), case 619.

${ }^{65}$ Pascale Ghazaleh, Masters of the trade: crafts and craftspeople in Cairo: 1750-1850, American University in Cairo Press, 1999, pp. 70-3.

\footnotetext{
${ }^{66}$ Amnon Cohen, The guilds of Ottoman Jerusalem, Leiden, Brill, 2001, pp. 82-3.

${ }^{67}$ Ghazaleh, op. cit., note 65 above, pp. 54-5.

${ }^{68}$ Ghazaleh, op. cit., note 60 above, p. 68 .
} 
surgeon in Bulāq (a district in Cairo), had not met the professional requirements by passing the examinations, and demanded that al-Hâwī take a oath before the court that he would not practise circumcision on any patient before being examined by trustworthy experts. ${ }^{69}$ This case shows that the Sheikh considered it his duty to prevent unqualified apprentices from treating patients until they had mastered the techniques of their craft, but he exercised his power mainly through the legal process. The reference in the legal record to an examination indicates that there were certain professional standards and criteria upon which the skills of medical craftsmen and apprentices were judged.

Being a member of a medical guild had certain benefits, most importantly, official recognition. Members of medical guilds were recognized as experts by local authorities. Judges usually consulted the heads of the medical guilds or medical master craftsmen before issuing sentences in cases of physical violence, suspicious deaths, or complaints of deficient inspection of slaves. A case dated 1024/1614 shows that the Head of the Surgeons' Guild was required to examine a dead body found in a public area to ascertain the cause of death. ${ }^{70}$ Another seventeenth-century case required a master surgeon to examine for physical defects a slave whose owner complained that he had been tricked into buying. ${ }^{71}$ By consulting the members of guilds, the state acknowledged them as experts in their fields (ahl al-khibrah), and thus provided them with an advantage over competitors who did not belong to a guild.

Another important consequence of the establishment of guilds was that they promoted certain standards of work and also religious tolerance among their members. ${ }^{72}$ Although biographical dictionaries rarely refer to non-Muslim medical practitioners, several primary sources assert that Jews and Christians constituted a sizeable group of medical healers. In the sixteenth-century, Dāwūd al-Antākī lamented that in Egypt the faqih (an expert in Islamic jurisprudence) went to a Jewish physician for medical advice. ${ }^{73}$ His contemporary, Sheikh 'Abd al-Wahāb al-Sha' arān̄i, a Sufi scholar, complained that even pious Muslims sought advice from Christian and Jewish physicians, and that Muslims relied on Jews to circumcise their sons. ${ }^{74}$ In the seventeenth century, the notables of Cairo recruited the Jewish physician Mūsà al-Rabbān as a private physician in their service. ${ }^{75}$ The religious tolerance of medical guilds was a positive influence in the careers of non-Muslim medical practitioners, providing them with security. A lawsuit brought against a number of Jewish physicians, practising in their hawänit (shops) beside al-Aqmar mosque, provides an example of a guild defending the interests of its members regardless of their religion. An unnamed group of Muslims accused the Jewish physicians of being incompetent, stating also that their hawänit were prejudicial to the mosque. However, Sheikh Badr al-din Hassan al-Shirbīnī, Head of the Physicians' Guild, and Sheikh Ahmad al-Shirbīn̄, another physician, were brought in as witnesses. They declared that these Jewish physicians had been practising for a long time

\footnotetext{
${ }^{69} \mathrm{BA}$, record $99(1026 / 1617)$, case 540 .

${ }^{70}$ Nelly Hanna, 'The administration of courts in Ottoman Cairo', in Hanna (ed.), op. cit., note 60 above, pp. 44-59, on p. 53.

${ }^{71}$ BA, 190 (1120/1708), case 1533.

${ }^{72}$ Raymond, op. cit., note 53 above, vol. 2, pp. 522-6; Abdul-Karim Rafeq, 'Craft organization, work ethics and the strains of change in Ottoman Syria', Journal of the American Oriental Society, 1991, 111 (3): 495-511, pp. 507-8.
}

\footnotetext{
${ }^{73}$ Dāwūd al-Antākī, op. cit., note 29 above, p. 4.

${ }^{74}$ Michael Winter, Society and religion in Ottoman Egypt: studies in the writings of 'Abd al-Wahhāb al-Sha'rān̄, New Brunswick, Transaction Books, 1982, p. 285.

${ }^{75}$ Muhsin Shuman, Al-Yahūd fi misr al-'uthman̄yah hattà al-qarn al-tas' 'ashar, 2 vols, Cairo, al-Hay'ah al-Mișrīyah al- 'Āmmah lil-Kitāb, 2000, vol. 2, p. 230.
} 


\section{Sherry Sayed Gadelrab}

in that place, which was well known to their clients, to whom the Jewish physicians gave excellent treatment and the most useful of medicines. The Head of the Guild of Physicians also brought a fatwa from the 'ulamā stating that if the presence of Jewish physicians did not cause any harm to Muslims, no one was allowed to harm them or force them out of their hawānit. ${ }^{76}$

\section{Guilds and Female Medical Practitioners}

In Ottoman Egypt, female providers of health care had a pivotal role in society. Women worked as physicians, surgeons and midwives, visited their patients in their homes and even sometimes had their own shops. ${ }^{77}$ Travellers' accounts, particularly that of Prospero Alpini, confirm the large number of female physicians practising in the country and give as the reason that female patients believed women had a greater understanding than men of uterine disease and other female-related ailments. ${ }^{78}$ Female physicians did not, however, provide medical care merely for women. Alpini refers to a certain Turkish female physician, who was respected by both her male and female clients, and praised her talent in treating women suffering from hysteria. ${ }^{79}$ Female physicians also worked in al-Manșūrī hospital, probably employed in the ward designated for female patients. ${ }^{80}$ However, in the account of Sari Eldin al-Ṣāigh, who was both Head of the Physicians' Guild and chief physician in al-Manșūrī hospital, we are told that his daughter succeeded him as chief physician. ${ }^{81}$ The promotion of a female physician to such an important rank would have been exceptional, but it indicates that the most qualified female physicians were, at least, recognized professionally even by their male counterparts.

Midwifery, in particular, was a female preserve, with women delivering babies, and providing advice on pregnancy, children's diseases, and other health issues of concern to women. Although some physicians and surgeons such as al-Zahrāwī mention different childbirth techniques, it is very unlikely that men actually assisted at childbirth. Instead, physicians and surgeons usually trained midwives in childbirth techniques such as the use of forceps and vaginal specula for the extraction of a dead foetus and the extraction of bladder stones. ${ }^{82}$ In medieval and early modern societies the midwife was held in high regard by both intellectuals and ordinary people. Ibn Khaldūn considered midwifery to be among the most honourable of professions, finding midwives better trained in childbirth than men and more knowledgeable of childhood ailments. ${ }^{83}$

The guild of midwives was composed exclusively of women, headed by the most experienced. Midwives were employed to provide expert advice or as witnesses in legal cases that concerned women, such as rape and abortion. In such cases, the court usually required

\footnotetext{
${ }^{76}$ BA, 145 (1078/1667), case 624.

${ }^{77}$ Umaymah Abū Bakr and Hudá al-Sa'dī, al-Nisā' wa-mihnat al-tibb fi al-mujtama 'àt al-Istämìyah, $Q 7 M-Q 17 M$, Cairo, Multaqá al-Mar' ah wa-al-Dhākirah, 1999, pp. 2-4.

${ }^{78}$ Alpin, op. cit., note 31 above, p. 13.

${ }^{79}$ Ibid., pp. 369-70.

${ }^{80}$ Amira el Azhary Sonbol, 'Doctors and midwives: women and medicine at the turn of the
}

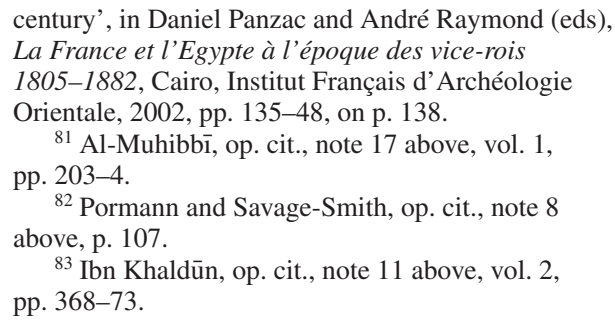


the attendence of two midwives: the main midwife of the district and the head of the guild or the chief midwife in the town. ${ }^{84}$

\section{Medical Guilds in Ottoman Egypt: The Extent of Success}

The primary evidence suggests that, although the medical guilds played a significant role as professional supervisory bodies, it cannot be argued, appealing though such an argument might be, that they regulated all medical practice. As Egypt was an Ottoman province, Egyptian physicians and medical practitioners who were members of guilds were not the only ones who had the right to practise medicine. There were no restrictions on any Ottoman subject who wanted to work in Egypt whether in medicine or in any other craft. Throughout this period, there was a free movement of knowledge and ideas, as well as labour, across the wide geographical zones ruled by the Ottoman sultans. Following the conquest of Egypt, Sultan Selim I ordered the removal of some of the most skilled Egyptian craftsmen to Istanbul. The Egyptian physician Badr al-din al-Qawșūnī, previously employed by the Mamluk sultans, became a physician at the Ottoman court, as did Emir Çelebi, formerly chief physician at al-Mansūrī hospital in Cairo. ${ }^{85}$ Similarly, many students from all over the empire travelled to Egypt to study at al-Manșūrī hospital, which was an important centre of medical learning. Raymond's study of the legacies of artisans and tradesmen in the seventeenth and eighteenth centuries indicates the presence of a number of Syrian Christian physicians in Egypt, some of whom were more favoured by the Mamluk emirs than their Egyptian counterparts. ${ }^{86}$ The authority of the medical guilds did not extend to preventing non-Egyptian practitioners from practising, or to supervising their activities. The investiture deed of the Head of the Surgeons' Guild stated clearly that the Sheikh had the authority to supervise only Egyptian surgeons but not al-arwam, a term used then to refer to Turks. Non-Egyptian medical practitioners, if their number were large enough, might have formed their own medical guilds. Many of them, particularly those who settled in Egypt, eventually became members of the Egyptian guilds. However, some physicians who moved from one Ottoman province to another offering their medical services remained independent of these bodies.

In fact, the inability of Egyptian medical professional organizations to monopolize medical activities and regulate all medical practice persisted until the nineteenth century. Despite Muhammad Ali Pasha's desire for independence, Egypt remained officially part of the Ottoman empire. This situation hindered the Egyptianization of the medical profession. When the Doctors' Council, in 1851, drew up a document stating that all foreign pharmacists were required to obtain permission through their consulates before they could open a pharmacy and produce medicines for sale, Ottoman pharmacists were exempted. ${ }^{87}$

Although guild regulations prevented craftsmen from opening shops without permission from the guilds, medical practitioners who exercised different medical procedures privately remained out of reach. Eviliyā Çelebi, for example, writes of "cruel and cold-hearted" surgeons (jarrāhin al-jalābah) who castrated slaves in the houses where these boys were kept. Many of their victims were left to suffer for days or bled to death. These surgeons did

\footnotetext{
${ }^{84}$ Sonbol, op. cit., note 80 above, pp. $138-9$.

${ }^{85}$ Esin Kahya and Aysegūl Demirhan Erdemir, Medicine in the Ottoman empire and other scientific
}

developments, Istanbul, Nobel Medical Publications, 1997, pp. $58 \& 73$.

${ }^{86}$ Raymond, op. cit., note 53 above, vol. 2, p. 493.

${ }^{87}$ Ghazaleh, op. cit., note 65 above, p. 59. 


\section{Sherry Sayed Gadelrab}

not belong to the surgeons' or the barber-surgeons' guilds, and thus their medical activities were not supervised by either. However, they had their own guild, which Çelebi placed on a level with those of the prostitutes, beggars and thieves, and their activities were inspected by the head of the police. ${ }^{88}$

But the most crucial reason why the medical guilds never succeeded in totally regulating all medical activities remains the pluralism of sources of medical knowledge. In Ottoman Egypt, as in other early modern societies, there was no consensus as to where medical authority lay. Different theories and therapies were shared by a wide spectrum of healers from learned physicians to the patient himself. Matthew Ramsey's study of medicine in early modern France suggests that it was not until the nineteenth century that the medical profession was strengthened and the division between professional and popular practitioners became sharper. ${ }^{89}$ Lucinda McCray Beier has argued that despite the efforts of occupational organization, "there was no medical profession in seventeenth-century England". The plurality of sources of medical knowledge made England at that time an open marketplace where both licensed and unlicensed healers presented their services to suffering patients. ${ }^{90}$

\section{Popular Healers}

A number of obstacles hinder our ability to examine objectively the wide variety of popular healers, whose activities are already overburdened with pre-judgment. Modern scholarship has assumed popular healers were illiterate, employed superstitious and irrational methods of healing, and were consulted only by the underprivileged and uneducated, in contrast to learned practitioners, who had a rich and educated clientele. Second, it is difficult to obtain a reliable picture of popular healers and their therapeutic methods. Our most extensive source for the Ottoman period is a book written by the nineteenth-century Egyptian doctor, 'Abd al-Rạ̣mān Ismā'il, who recorded the practices of many magicians and other popular healers specifically to warn people against them. It is necessary, therefore, to approach his work with caution. ${ }^{91}$ An objective research of popular healers has to take into consideration the different intellectual and cultural contexts in which they practised. Practitioners such as magicians and astrologers, whom we now regard as popular, had clients from a variety of educational and social backgrounds, ranging from poor women suffering infertility problems, to the Ottoman sultan himself. It is difficult, and almost impossible, to differentiate between the activities of "learned" versus "popular" healers. Both groups employed Galenic, prophetic, magical and folk medicine as the basis of their practices.

In Ottoman Egypt, it is possible to distinguish two main approaches towards disease among both educated and uneducated people. The first defines disease in Galenic terms, while the other stresses the religious and supernatural causation of disease. These pluralist interpretations of disease are reflected in the writings of intellectuals, physicians and historians. When the Ottoman traveller Evliyā Çelebi visited Egypt, he used the Galenic theory of humoral pathology to explain common diseases, but still considered some, such

\footnotetext{
${ }^{88}$ Evliyā Çelebi, Siyāhatnāmah Misr, Cairo, al-Hay’ah al-Mișrīyah al- 'Āmmah lil-Kitāb, 2009, pp. 484-5.

${ }^{89}$ Matthew Ramsey, Professional and popular medicine in France, 1770-1830, Cambridge University Press, 1988.
}

\footnotetext{
${ }^{90}$ Lucinda McCray Beier, Sufferers and healers: the experience of illness in seventeenth-century England, London, Routledge and Kegan Paul, 1987.

91 'Abd al-Rahmān Ismā‘il, Tiibb al-rikkah, 2 vols, Cairo, Mạtba'at al-Baahīyah, 1892-1894.
} 
as elephantiasis, as a punishment from God. Elephantiasis, he commented, attacked the descendants of the Yazidis (supporters of Caliph Yazid in his struggle against the prophet's grandson al-Hussayn), who kicked al-Hussayn in the head, and thus their legs became swollen. ${ }^{92}$ The sixteenth-century Egyptian historian al-Ishaqi $\overline{1}$ considered sodomy a disease that God sent to humiliate despots. ${ }^{93}$

In some Muslim societies such as Egypt, pre-Islamic beliefs in supernatural influences and invisible creatures were a part of the cultural heritage, shared by people from different religions and social backgrounds. The ancient belief in the evil eye and its adverse effects continued to survive strongly amongst early modern Egyptians. ${ }^{94}$ They believed that illfavoured people, sterile or old women could cause disease and even death by a malevolent look. The nineteenth-century traveller Edward William Lane pointed out that urban and rural Egyptians attributed many diseases, including fevers, to the evil eye. ${ }^{95}$ Religious scholars accepted the belief as based on a prophetic tradition that asserts that the evil eye is a reality. It was, therefore, so well established in formal Islam that it was difficult to challenge even by western-educated nineteenth-century doctors. ${ }^{96}$ For instance, 'Abd al-Rahmān Ismā'il tried to explain the evil eye rationally as an electro-magnetic force within every human being, which could be good or bad, depending on the character of the person. ${ }^{97}$

Similarly, the popular belief in jinn (spirits) was shared across the social strata by religious scholars, physicians and the uneducated urban people and villagers. According to the Qur'ān, the jinn were invisible creatures made by God from smokeless flames. The world of jinn was not separated from that of humans because each human being had a jinnī brother or sister. $^{98}$ Some religious scholars asserted that denial of the existence of jinn was equivalent to heresy and believed that possession of human bodies by jinn could cause diseases such as insanity and epilepsy. ${ }^{99}$ The medieval and early modern explanation of the plague was that it was caused by jinn piercing people. ${ }^{100}$ Common people associated the jinn not only with mental diseases but also with infant diseases and child mortality. If a wife lost her children, it was believed that her husband's jinnī's sister, out of jealousy, did not want the wife to have any children. ${ }^{101}$ Learned physicians such as the sixteenth-century Dāwūd al-Anțākī shared the belief in jinn and combined religious and Galenic interpretations of the plague.

\footnotetext{
${ }^{92}$ Gary Leiser and Michael Dols, 'Evliyā

Chelebi's description of medicine in

seventeenth-century Egypt', Sudhoffs Archiv, 1987,

71: 197-216, pp. 203-5.

${ }^{93}$ Muhammad Ishāqū, Kitāb Latà' if akhbār al-uwal fi-man tasarrafa fi Miș min arbāb al-duwal, Al-Mansūrah, Maktabat al-Īmān, 2000, pp. 13-15.

${ }^{94}$ For a discussion of the non-Islamic origins of many popular beliefs, see Edward Westermarck, Pagan survivals in Mohammedan civilization, Amsterdam, Philo Press, 1973.

${ }^{95}$ Edward William Lane, An account of the manners and customs of modern Egyptians, American University in Cairo Press, 2003 (lst ed. published in 1836-7), pp. 57-8.

${ }^{96}$ For more information on the evil eye in prophetic medical literature, see "Abd Allāh al-Sharqāwī, Fath al-mubd̄̄ bi-sharh mukhtasar al-Zabìdı̀, 3 vols, Cairo, Maktabat Mustafā al-Bābī al-Halabī, 1920, vol. 3, p. 292; Cyril Elgood,
}

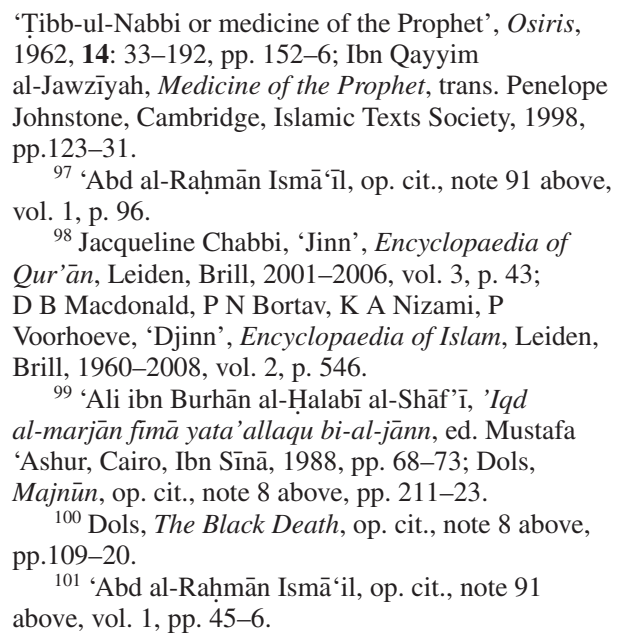




\section{Sherry Sayed Gadelrab}

According to al-Antākī, the plague resulted from the miasma which usually occurred in battlefields, graveyards and deserted areas where jinn normally live and, therefore, there was no contradiction between religious and medical interpretations of plague. ${ }^{102}$

In such an intellectual context, a large number of popular, mainly illiterate, healers practised medicine freely in urban and rural areas. People consulted popular healers about many of their ailments, but some of these healers were famous for their expertise in the treatment of certain specific conditions. For many, the practice of medicine was their main source of income, others charged no money for their services or took only food or other gifts after the patient was cured. Popular healers used diverse methods: spiritual and magical healing, astrological medicine, and folk medicine or they employed surgical techniques similar to those of trained surgeons or physicians.

\section{Sufi Sheikhs}

In Ottoman Egypt, Sufi Sheikhs were among the popular healers most widely consulted by both rich and poor, as well as by the Turkish ruling elite. Sufism was widespread in Mamluk Egypt, and, under Ottoman rule, the number of Sufi orders multiplied and their activities intensified. Mamluks, 'ulamā, merchants, as well as labourers, craftsmen and villagers became members of Sufi orders. These orders were, however, divided into different types, those for the rich and better-educated and those for the poor and illiterate. Although Sufism was respected by 'ulamā and intellectuals, Sufi orders for the common people were accused of being less orthodox and less careful in observing the laws of Islam. ${ }^{103}$ Members of the Sufi orders were believed to be repositories of barakah, a blessed virtue conveniently translated as holiness, because of their nearness to God. As a consequence, it was believed that some Sufi sheikhs possessed supernatural healing powers and could perform marvels (karāmāt), attributed only to prophets, by transmitting some of their barakah to their patients through physical contact or the transfer of body fluids (sweat, spittle, semen, etc.). ${ }^{104}$ The paralysed Sufi Sheikh Ahmad al-Satīhah spat in some oil and ordered a woman who had been paralysed for four years to cover her body with the oil, and she was healed instantly. ${ }^{105}$ Another Sufi, Sheikh Ahmad al-Shirbīnī, predicted to his son and closest followers that he would die on a certain date and that patients touching their bodies with the water used for bathing his dead body would be healed immediately, even if they were chronically ill with leprosy or blind. ${ }^{106}$

Although educated, religious scholars accepted that karāmāt were rationally possible, some of them questioned whether Sufi sheikhs were capable of performing these marvels. Followers of Sufism, especially some among the 'ulama $\bar{a}$, defended them by claiming that as God is the source of all barakah, Sufi sheikhs were capable of performing miracles only as an attribute of their barakah. ${ }^{107}$ The stories of karamat were generally accepted by

\footnotetext{
${ }^{102}$ Dāwūd Al-Anțākī, op. cit., note 29 above, vol. 2, p. 120.

${ }^{103}$ Michael Winter, Egyptian society under Ottoman rule, 1517-1798, London, Routledge, 1992, p. 130; idem, Society and religion, op. cit., note 74 above, pp. 88-125.

${ }^{104}$ G S Collin, 'Baraka', Encyclopaedia of Islam, op. cit., note 98 above, vol. 1, p. 1032; Dietrich Von Denfer, 'Baraka as basic concept of Muslim popular
}

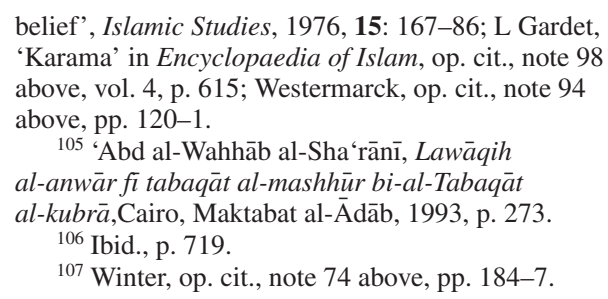


intellectuals such as 'Abd al-Rahmān al-Jabartī, who only questioned those attributed to Sufis from the common orders or to animals. ${ }^{108}$

\section{Magicians}

There were also magicians who, like the Sufi sheikhs, were believed to possess specific skills for bringing good fortune, finding missing objects, predicting the future, identifying thieves, and treating a variety of ailments and ills, especially those caused by spells. When Edward Lane visited Egypt in the 1830s, he commented on the talent of many of these magicians, which he believed was inherited from the ancient Egyptians. ${ }^{109}$ These men could be Sufi sheikhs known for their knowledge of some magical arts, simple local village sheikhs of traditional elementary schools $(k u t t a \bar{b})$ writing amulets and charms for their neighbours, or local magicians (sahhärīn) found in urban neighbourhoods and villages. ${ }^{110}$ There were also Jewish and Christian magicians, who, despite the warnings of religious scholars against them, seem to have been popular figures in the eighteenth century.

Although religious scholars and fuqaha did not agree on the legitimacy of learning and/or practising medicine, they accepted magic as real because it was mentioned in both the Qur'ān and prophetic sayings, and believed it could influence people physically. The prophet regarded sorcery as one of the greatest sins of mankind, and thus a sorcerer should be condemned to death. ${ }^{111}$ However, the studies by Toufic Fahd and Emilie Savage-Smith demonstrate that religious scholars differentiated between permitted and prohibited (harmful) magic. Most magical medical practices such as the use of charms, talismans and sympathetic magic belonged to the category of what was permitted. ${ }^{112}$ This could explain Lane's observation that the Egyptians divided magic into good magic (sih $r$ ' $u l w \bar{l}$ ), which relied on the support of God, angels, good jinn and the properties of the names of God, and bad magic (sìhr suffl), in which the sorcerer relied on the forces of demons and evil jinn. ${ }^{113}$

Magicians used many therapeutic techniques to heal their patients. Some claimed to be married to jinn, or capable of conjuring (istihdār) them up through specific formulas (ta'a $\bar{a} \bar{\imath} \mathrm{m}$ ) and thus exorcizing them from the bodies of patients believed to be possessed, or they employed jinn to bring medicines that would cure all ailments. ${ }^{114}$ Other magicians wrote charms and religious prayers to be hung around the neck for protection against

\footnotetext{
${ }^{108}$ Winter, Egyptian society, op. cit., note 103 above, pp. 148-9; 'Abd al-Raḥmān al-Jabartī, 'Ajaib al-athar fi al-tarājim wa al-akhbār, 4 vols, Cairo, Madbuli Library, 1997, vol. 3, pp. 119-20.

${ }^{109}$ Lane, op. cit., note 95 above, p. 238.

${ }^{110}$ B G Martin, 'A short history of the

Khalwatiyah Order of Dervishes', in Nikki R Keddie (ed.), Scholars, saints and Sufis: Muslim religious institutions in the Middle East since 1500, Berkeley, University of California Press, 1972, pp. 275-95.

${ }^{111}$ Toufic Fahd, 'Sihr', Encyclopedia of Islam, op. cit., note 98 above, vol. 9, p. 567; Lane, op. cit., note 95 above, p. 207.

${ }^{112}$ For more on this debate, see Emilie Savage-Smith, 'Magic and Islam', in
}

Francis Maddison and Emilie Savage-Smith (eds), Science, tools and magic, London, The Nour Foundation in association with Azimuth Editions and Oxford University Press, 1997, p. 59; Fahd, 'Sihr', op. cit., note 111 above, p. 567; Toufic Fahd, 'Le monde du sorcier en Islam', in Sources orientales, vol. 7, Paris, du Seuil, 1966, pp. 157-206.

${ }^{113}$ Lane, op. cit., note 95 above, pp. 263-4.

${ }^{114}$ Hājjī Khalīfah, op. cit., note 14 above, vol. 2, pp. 114-15; Michael Dols, 'The theory of magic in healing', in Emilie Savage-Smith (ed.), Magic and divination in early Islam, Aldershot, and Burlington, VT, Ashgate/Variorum, 2004, pp. 87-101, pp. 98-9; 'Abd al-Rahmān Ismā'il, op. cit., note 91 above, vol. 1, pp. 27-32, 63 . 


\section{Sherry Sayed Gadelrab}

pestilence, infirmities and the evil eye. ${ }^{115}$ Some prepared secret remedies, which allegedly had a mysterious power for treating many conditions. ${ }^{116}$

Dols' study of this subject reveals that magic was recognized as an accepted form of healing not only by ordinary people but by intellectuals also. The Arabic term tibb, meaning medicine, was understood as counter-sorcery. Some scholars such as Ibn Khaldūn asserted, "no intelligent person should deny magic". ${ }^{117}$ Hàjjì Khalifah believed that magic was the science that could "explain all inexplicable events and strange accidents that could not be accepted by the greatest of minds". ${ }^{118}$ Evliyā Çelebi believed that the amulets and talismans made in the citadel of Cairo were effective in curing people of colic, fevers, malaria and plague. ${ }^{119}$ For these intellectuals, as for uneducated people, magic could be an alternative cure for many diseases that could not be treated by orthodox medicine.

Some physicians also used magical and spiritual techniques, often referred to as tibb rawhīnī. The Syrian physician Ibn al-Hakìm's fame for treating his patients with talismans and magic squares opened for him the gates of power and wealth, when the Ottoman sultan, seeking a physician talented in tibb rawhāañ , employed him as a court physician. ${ }^{120}$ Dāwūd al-Antākī's Tadhkirat included instructions on how to make talismans and charms for the treatment of each disease. ${ }^{121}$ Many learned medieval and early modern physicians believed that they could employ the occult properties (khawās) of animals, plants and minerals in treatments. The 'ilm al-khawās (knowledge of occult properties) had its roots in Greek medical traditions, based on the belief that everything in nature has occult forces that could be activated to cure a disease or to bring good luck or good fortune. ${ }^{122}$ Carrying the right wing of a cuckoo was recommended for treating memory loss, while lepers were advised to bury a dead snake's skin and then eat the worms once they appeared. ${ }^{123}$ Some physicians recommended the use of $b \bar{a} d z a h r$ stone as an antidote against poison, which was a common therapeutic among illiterate and educated Egyptians alike. ${ }^{124}$

\section{Astrologers}

As a discipline, astrology was based on Aristotelian philosophy. The earth is at the centre of the universe and thus is the passive recipient of the activities of celestial spheres that revolve around it. Astrology is thus the science by which the astrologer, on the basis of sound astronomical knowledge, can predict how the movements of the heavenly bodies may affect earthly events. ${ }^{125}$ Because of astrologers' claims that celestial bodies influence

\footnotetext{
115 ‘Abd al-Raḥmān Ismā‘il, op. cit., note 91 above, pp. 22-3; Lane, op. cit., note 95 above, pp. 217-18; Ibn Qayyim al-Jawziyah, op. cit., note 96 above, pp. 132-42.

116 'Abd al-Rahmān Ismā'il, op. cit., note 91 above, pp. 16, 18-19, 55, 86.

${ }^{117}$ Dols, op. cit., note 114 above, p. 88.

${ }^{118}$ Hājjī Khalifah, op. cit., note 14 above, vol. 2, p. 21.

${ }^{119}$ Leiser and Dols, op. cit., note 92 above, pp. 199-200.

${ }^{120}$ Al-Muhibbī, op. cit., note 17 above, vol. 1, p. 96.

${ }^{121}$ Dāwūd al-Antākī, op. cit., note 29 above, pp. 125-31.
}

\footnotetext{
${ }^{122}$ Manfred Ulmann, Islamic medicine, Edinburgh University Press, 1978, p.101.

${ }^{123}$ Dāwūd al-Anțākī, op. cit., note 29 above, vol. 2, p. 92; Ahmad al-Qalyūbī, Tadhkirat al-Qalyūbì, Cairo, 1890, p. 8.

${ }^{124}$ Lane, op. cit., note 95 above, p. 8; Shams al-din Muhammad Al-Qawsūnī, 'Al-Maqālah fī Hajar al-bādzahr al-haywān̄̄', manuscript, Dār al-Kutub al-Misrīyah, Cairo, Egypt, tibb 117.

${ }^{125}$ C Burnett, 'Astrology', in Gudrun Krämer, Denis Matringe, John Nawas and Everett Rowson (eds), Encyclopaedia of Islam, Leiden, Brill, 2010, vol. 3, http://www.brillonline.nl.lib.exeter.ac.uk; Hạjjji Khalifah, op. cit., note 14 above, vol. 1, p. 57.
} 
events, some religious scholars were not tolerant of astrology. The medieval religious scholar Ibn Taymiyah, for example, forbade the study and practice of astrology, claiming it produced more harm than good; others permitted the study of astrology provided astrologers acknowledged that God is the main source of any influence on earthly events. ${ }^{126}$

In practice, however, astrologers (munajimūn) could be found everywhere from the palaces of the Ottoman sultans to the poorest districts in Egypt. The sultans consulted astrologers before embarking on an important action or event. Some stories from the court showed sultans' strong belief in the ability of astrologers to predict the future. When Sultan Bayazid's astrologer warned him that one of his yet unborn sons would kill him, the Sultan ordered the midwives to kill all his newly born male infants. ${ }^{127}$ On the popular level, astrologers were consulted about childbirth, health and disease. They predicted the sex of children, determined whether childbirth would be difficult or easy, and foretold the illnesses that would affect their clients. ${ }^{128}$ Besides astrologers, there were also geomancers who drew lines in the sand and told people their future. In Ottoman and nineteenth-century Egypt, most geomancers and astrologers were Sudanese or Moroccan men and women, and it was believed that these arts had originated in North Africa. ${ }^{129}$

Learned physicians used astrological techniques for questions related to health and disease. Some even asserted that a physician who did not master the art of astrology could be risking the lives of his or her patients. Determining the horoscope of a child was regarded as a tool for physicians to ascertain the diseases that would afflict the child in the future, and, consequently, the most useful treatments for his or her case. The position of the stars determined the best time to perform bloodletting or to apply treatments. ${ }^{130}$

\section{Women as Popular Healers}

In Ottoman Egyptian society, female popular healers were Sufi Sheikhahs, magicians, astrologers, geomancers, and they were even more visible than their male counterparts. Most clients of female popular healers were other women, who resorted to folk and magical medicine not merely to prevent or cure general health problems such as plague, fevers or other diseases, but also when seeking a solution for many of their private worries such as barrenness, infertility, childbirth, and child mortality, which could jeopardize their marriages,

\footnotetext{
${ }^{126}$ The religious debates, which originated in the medieval period, centred on whether the celestial bodies indicated or actually caused the sublunar movements and on the extent of their influence on events in human lives. For more on this debate, see Yahya J Michot, 'Ibn Taymiyya on astrology: annotated translation of three fatwas', in Savage-Smith (ed.), op. cit., note 114 above, pp. 270-340. p. 309 .

${ }^{127}$ Ishāqīi, op. cit., note 93 above,

${ }^{128}$ Lane, op. cit., note 95 above, pp. 217-64; George Saliba, 'The role of the astrologer in Islamic society', in Savage-Smith (ed.), op. cit., note 114 above, 341-63.

${ }^{129}$ Lane, op. cit., note 95 above, pp. 217-64; Saliba, op. cit., note 128 above.
}

\footnotetext{
${ }^{130}$ The Arabs recognized geomancy as a complex divinatory art. It is believed that the angel Jibril taught it to the Prophet Idris, who in turn taught it to Tumtum al-Hind $\overline{1}$, a legendary figure supposed to be living in India. Khalaf al-Barbarī, a contemporary of the prophet, learnt the art after travelling to India and studying the books of Tumtum al-Hindī. Khalaf taught the art to a number of students. The name of a North African, Abū Abduallah al-Zanātī, figured as one of the authorities, which explains the common belief that North Africans were generally talented in geomancy. Emilie Savage-Smith and Marion B Smith, Islamic geomancy and a thirteenth-century divinatory device, Malibu, Undena Publications, 1980, pp. 1-3; G Vadka, 'Idrīs', Encyclopedia of Islam, op. cit., note 98 above, vol. 3, p. 1030; J Pederson, 'Djbrīl', ibid., vol. 2, p. 362.
} 


\section{Sherry Sayed Gadelrab}

their social and economic prestige, and even their lives. ${ }^{131}$ Some women claimed to be capable of conjuring jinn and employing them to treat barren women. ${ }^{132}$ Others prescribed certain magical procedures for their female clients such as passing over the bodies of decapitated criminals to avert infertility or burying their placentas with the intestines of a black chicken under their doorsteps of their houses to protect their infants. ${ }^{133}$

Wives in early modern Egyptian society were responsible for dispensing medical care for their families through a tradition of domestic medicine, based on empirical knowledge, usually transmitted orally from one generation to the next. Some of these household remedies were originally derived from learned medicine, and some domestic medical drugs were occasionally mentioned in medical literature, especially when these had a reputation of success. Dāwūd Al-Antākī, for example, tells us that Egyptian women used to make their sons drink lead ceruse (isfidāj) to remove body odour. ${ }^{134}$

\section{Conclusion}

This preliminary investigation of the various categories of medical healers in Egypt in the Ottoman period shows that a wide variety of medical healers made up a pluralist medical system. Galenism was not restricted to learned practitioners, even popular and folk practitioners were familiar with some traditional Galenic remedies and techniques. Physicians, like the ordinary people, believed that a disease could be caused by the evil eye or jinn, and prescribed magical potions besides traditional therapies. Therefore, our modern distinction between rational and learned medicine, and folk and popular medicine does not apply to this situation.

As this study argues, the traditional distinction between folk, traditional or popular, and learned rational medicine does not apply to the status of medical practitioners in early modern Egyptian society. Rather medical personnel in Ottoman Egypt were part of a medical system where the distinction between sources of medical knowledge was blurred. Learned and traditional healers shared all types of medical therapies. For the desperate patient it mattered little whether a healer was learned or illiterate, physician or magician, as long as he or she could, or claimed to be able to, heal the sick.

However, this investigation shows that the medical scene was not totally uncontrolled. Guilds were responsible for ensuring professional standards and promoting work values amongst the members of the craft, regardless of their religion, making use of local authorities such as the law courts, to verify their members' credentials or prevent the unqualified from working. A further scrutiny of court records could well reveal even more important information about medical healers and the mechanisms of their guilds. The role of the guilds could also be regarded as paving the way for the professionalization of medicine in nineteenth-century Egypt. I hope that future studies will examine the roots of nineteenthcentury medical reforms in the organization of the medical profession in Ottoman Egyptian society.

\footnotetext{
${ }^{131}$ Anon., Dhayl Tadhkirat Dawūd, published as an annex to Dāwūd al-Anțākī, Tadhkirat, op. cit., note 29 above, p. 109.

132 'Abd al-Rahmān Ismā'il, op. cit., note 91 above, vol. 2, pp. 3-5.
}

\footnotetext{
${ }^{133}$ Ibid., vol. 1, pp. 45-6.

${ }^{134}$ Dāwūd al-Anțākī, op. cit., note 29 above, vol. 1, p. 103.
} 